\title{
Effect of Muriate of Potash (MOP) and Sulphate of Potash (SOP) on Growth Characters of Green gram (Vigna radiata (L.) Wilczek) cv. VBN 2 in Pot and Field Condition
}

\author{
G. Poovizhi Sindhu ${ }^{1}$, K. Swetha Reddy ${ }^{1}$, J. Gunasekar ${ }^{2}$ and Maragani Vamshi ${ }^{1}$ \\ ${ }^{1}$ Department of Soil Science and Agricultural Chemistry, ${ }^{2}$ Department of Genetics and Plant \\ Breeding, Faculty of Agriculture, Annamalai University, Annamalai Nagar, Chidambaram, \\ Tamil Nadu - 608002, India \\ *Corresponding author
}

\section{A B S T R A C T}

\section{Keywords}

Green gram,

Potassium, $\mathrm{K}_{2} \mathrm{SO}_{4}$, Growth characters, Pot experiment, Field experiment

Article Info

Accepted:

20 January 2019

Available Online:

10 February 2019
A pot culture and field experiment was conducted to study the effect of potassium on growth characters of green gram $\mathrm{cv}$. VBN 2. The treatments used viz., $\mathrm{T}_{1}$ - Absolute control, $\mathrm{T}_{2}$ - control $\mathrm{N}, \mathrm{P},(-\mathrm{K}), \mathrm{T}_{3}-10 \mathrm{~kg}$ of $\mathrm{K}_{2} \mathrm{O}$ $\mathrm{ha}^{-1}, \mathrm{~T}_{4}-20 \mathrm{~kg}$ of $\mathrm{K}_{2} \mathrm{O} \mathrm{ha}^{-1}, \mathrm{~T}_{5}-30 \mathrm{~kg}$ of $\mathrm{K}_{2} \mathrm{O} \mathrm{ha}^{-1}, \mathrm{~T}_{6}-40 \mathrm{~kg}$ of $\mathrm{K}_{2} \mathrm{O} \mathrm{ha}{ }^{-1}$, $\mathrm{T}_{7}-10 \mathrm{~kg}$ of $\mathrm{K}_{2} \mathrm{SO}_{4} \mathrm{ha}^{-1}, \mathrm{~T}_{8}-20 \mathrm{~kg}$ of $\mathrm{K}_{2} \mathrm{SO}_{4} \mathrm{ha}^{-1}, \mathrm{~T}_{9}-30 \mathrm{~kg}$ of $\mathrm{K}_{2} \mathrm{SO}_{4} \mathrm{ha}^{-1}$, $\mathrm{T}_{10}-40 \mathrm{~kg}$ of $\mathrm{K}_{2} \mathrm{SO}_{4} \mathrm{ha}^{-1}$. The results revealed that application of $\mathrm{T}_{10}-40$ $\mathrm{kg}$ of $\mathrm{K}_{2} \mathrm{SO}_{4} \mathrm{ha}^{-1}$ recorded higher values for growth characters viz., plant height, number of leaves plant ${ }^{-1}$, number of branches plant ${ }^{-1}$, number of nodules plant ${ }^{-1}$, leaf area index and chlorophyll content respectively over control.

\section{Introduction}

Pulse consumption is increasing globally due to their high nutritional value and low glycemic index. Pulses are categorized as the most important dietary predictor of survival in older citizens of various ethnicities and are the key factor in increasing the life span of populations (Darmadi-Blackberry et al., 2004). In India pulse crops are grown in an area of 139.09 (MT) with an annual production level of 86.98 (MT) and productivity of about $639 \mathrm{~kg} \mathrm{ha}^{-1}$ during 2016-2017. Production of green gram during Kharif season is 1.02 and 1.35 million tonnes in 2015-2016 and 2016-2017 respectively (Anon, 2017). Pulses have double the amount of proteins than cereals. The pulse protein particularly from the lentil is deficient in methionine and cysteine (sulfur containing amino acids) while rich in lysine (Belitz and Grosch, 1996). The pulses also contain a variety of anti-nutrient factors (ANFs) such as the lectins, proteinase inhibitors, non-protein 
amino acids, gums, tannins, cynogens, saponins, alkaloids, phytates, etc. which are mostly destroyed in soaking, washing, cooking, and other processes (Ali and Muzquiz, 1998). Green gram is commonly known as mung bean in the Indian subcontinent and is widely grown in all Asian countries. $100 \mathrm{~g}$ of greengram gives 30 calories and consists approximately $3 \mathrm{~g}$ proteins, $6 \mathrm{~g}$ carbohydrates and $2 \mathrm{~g}$ dietary fibers. It provides about $15 \%$ and $45 \%$ of the recommended dietary allowance of calcium and iron, respectively. Greengram is almost nil in raffinose or other oligosaccharides and is free of flatulence-causing agent, making it suitable for convalescent, baby or senior citizen foods.

Potassium is one of the essential plant nutrients which play a vital role in various physiological, biochemical activities and are required in high amounts to maintain adequate crop growth and sustainable crop production (Mengel and Kirkby, 1987).Potassium is not only a constituent of the plant structure but it also has a regulatory function in several biochemical processes related to protein synthesis, carbohydrate metabolism and enzyme activation (Hasanuzzaman et al., 2018).

The quantity of potassium absorbed by roots is second to that of nitrogen for most of the cultivated plants. Due to intensive cropping, continuous manuring and limited or no use of potassium fertilizers, the available potassium status of the soils has depleted. Soils have begun to show response to potassium application particularly under intensive use of nitrogen and phosphorus fertilizers. Sufficient amounts of potassium is required for improving the yield and quality of different crops because of its effect on photosynthesis, water use efficiency and plant tolerance to diseases, drought and cold as well for making the balance between proteins and carbohydrates.

\section{Materials and Methods}

\section{Pot culture experiment}

The pot culture experiment was conducted in pot culture yard of Department of Soil Science and Agricultural Chemistry, Faculty of Agriculture, Annamalai University, Annamalainagar, Cuddalore district, Tamil Nadu, India, located at $11^{\circ} 24^{\prime} \mathrm{N}$ latitude and $79^{\circ} 41^{\prime} \mathrm{E}$ longitude with an altitude of +5.79 $\mathrm{m}$ above mean sea level.

\section{Pot preparation}

The soil collected from the field shade dried and broken into smaller clods using wooden mallet. Forty kilogram of processed soil was filled in earthen pots, which was maintained $22.5 \mathrm{~cm}$ soil depth and $7.5 \mathrm{~cm}$ space above the soil surface, so as to provide space for irrigation.

\section{Field experiment}

The field experiment was conducted at the Thennavarayanallur, Thiruvarur Taluk, Thiruvarur District- 610103, Tamil Nadu, India, located at between $10^{\circ} 20^{\prime} 11^{\circ} 07^{\prime}(\mathrm{N}-\mathrm{S})$ latitude and between $79^{\circ} 15^{\prime}-79^{\circ} 45^{\prime}(\mathrm{E}-\mathrm{W})$ longitude with an altitude of $10 \mathrm{~m}$ above mean sea level.

\section{Treatment details}

$\begin{array}{lll}\mathrm{T}_{1} & = & \text { Absolute control } \\ \mathrm{T}_{2} & = & \text { Control N, } \mathrm{P}_{2} \mathrm{O}_{5} \text { and }(-\mathrm{K}) \\ \mathrm{T}_{3} & = & 10 \mathrm{~kg} \text { of } \mathrm{K}_{2} \mathrm{O} \mathrm{ha} \\ \mathrm{T}_{4} & = & 20 \mathrm{~kg} \text { of } \mathrm{K}_{2} \mathrm{O} \mathrm{ha} \\ \mathrm{T}_{5} & = & 30 \mathrm{~kg} \text { of } \mathrm{K}_{2} \mathrm{O} \mathrm{ha} \\ \mathrm{T}_{6} & = & 40 \mathrm{~kg} \text { of } \mathrm{K}_{2} \mathrm{O} \mathrm{ha}^{-1} \\ \mathrm{~T}_{7} & = & 10 \mathrm{~kg} \text { of } \mathrm{K}_{2} \mathrm{SO}_{4} \mathrm{ha}^{-1} \\ \mathrm{~T}_{8} & = & 20 \mathrm{~kg} \text { of } \mathrm{K}_{2} \mathrm{SO}_{4} \mathrm{ha}^{-1} \\ \mathrm{~T}_{9} & = & 30 \mathrm{~kg} \text { of } \mathrm{K}_{2} \mathrm{SO}_{4} \mathrm{ha}^{-1} \\ \mathrm{~T}_{10}= & 40 \mathrm{~kg} \text { of } \mathrm{K}_{2} \mathrm{SO}_{4} \mathrm{ha}^{-1}\end{array}$




\section{Land preparation}

The plots selected for experiment was ploughed by power tiller driven rotovator and ploughed several times followed by laddering to obtain a good tilth. Weeds and stubbles were removed and the large clods were broken into smaller pieces to obtain a desirable tilth of soil for sowing of seeds. Finally, the land was leveled and plots were laid according to experimental layout.

\section{Fertilizer application}

The experimental plots received a fertilizer schedule according to the treatments. The $\mathrm{N}$, $\mathrm{P}_{2} \mathrm{O}_{5}$ were applied by basal according to the treatments and required quantity of MOP and SOP were applied in the experimental plots.

\section{After care}

The weeding was done by hand hoeing. First hoeing was done on the 15 DAS and the second on 30 DAS. Need based plant protection measures were taken.

\section{Experimental design}

The factorial experiment was laid out in a Randomized Block Design (RBD) with three replications. A recommended dose of fertilizers $25 \mathrm{Kg}$ of $\mathrm{N}$ : $50 \mathrm{~kg}$ of $\mathrm{P}_{2} \mathrm{O}_{5} \mathrm{ha}^{-1}$ was applied to all plots in the form of urea and SSP respectively. Variable doses of $\mathrm{K}_{2} \mathrm{O}$ was applied in the form of MOP and SOP as per treatment schedule except absolute control and control $(-\mathrm{K})$. Five plants from each plot were selected as random and also plants from each pot were tagged for the data collection. The following growth characters viz., plant height, number of leaves plant ${ }^{-1}$, number of branches plant ${ }^{-1}$, number of nodules plant ${ }^{-1}$, leaf area index and chlorophyll content were observed and data collected. Data analysis was done statistically which was suggested by Gomez and Gomez (1984).

\section{Results and Discussion}

\section{Pot culture experiment}

\section{Plant height (cm)}

Application of increased levels of potassium in the form of MOP and SOP resulted in significantly increased in plant height. The treatment $\mathrm{T}_{1}$ recorded the lowest plant height of $10.9 \mathrm{~cm}$ and the treatment $\mathrm{T}_{10}$ recorded the highest plant height of $33.7 \mathrm{~cm}$. However the treatment $\mathrm{T}_{6}$ which recorded $33.4 \mathrm{~cm}$ was on par with treatment $\mathrm{T}_{10}$. The treatments $\mathrm{T}_{9}$ and $\mathrm{T}_{5}$ recorded plant height of 30.1 and $29.6 \mathrm{~cm}$ which were found to be statistically similar. Further the treatments $T_{8}$ and $T_{4}$ recorded plant height of 26.6 and $26.2 \mathrm{~cm}$ which were on par with each other. It was followed by treatments $\mathrm{T}_{7}$ and $\mathrm{T}_{3}$ recorded a plant height of 23.3 and $22.9 \mathrm{~cm}$ which were statistically on par. The treatment $\mathrm{T}_{2}$ recorded a plant height of $19.5 \mathrm{~cm}$ at 30 DAS. The treatments $\mathrm{T}_{1}$ recorded the lowest plant height of $14.8 \mathrm{~cm}$ and the treatment $\mathrm{T}_{10}$ recorded the highest plant height of $43.6 \mathrm{~cm}$. However, the treatment $\mathrm{T}_{6}$ which recorded $43.2 \mathrm{~cm}$ was on par with treatment $T_{10}$. The treatments $T_{9}$ and $\mathrm{T}_{5}$ recorded plant height of 39.0 and $38.4 \mathrm{~cm}$ which were found to be statistically similar. Further the treatments $T_{8}$ and $T_{4}$ recorded plant height of 34.6 and $34.2 \mathrm{~cm}$ which were on par with each other. It was followed by treatments $\mathrm{T}_{7}$ and $\mathrm{T}_{3}$ recorded a plant height of 30.5 and $29.9 \mathrm{~cm}$ which were statistically on par. The treatment $T_{2}$ recorded a plant height of $25.6 \mathrm{~cm}$. The treatment $\mathrm{T}_{1}$ recorded the lowest plant height of $27.3 \mathrm{~cm}$ and the treatment $\mathrm{T}_{10}$ recorded the highest plant height of $60.0 \mathrm{~cm}$. However, the treatment $\mathrm{T}_{6}$ which recorded $59.6 \mathrm{~cm}$ was on par with treatment $\mathrm{T}_{10}$. The treatments $\mathrm{T}_{9}$ and $\mathrm{T}_{5}$ recorded plant height of 54.8 and $54.1 \mathrm{~cm}$ which were found to be statistically similar. Further the treatments $T_{8}$ and $T_{4}$ recorded plant height of 49.8 and $49.3 \mathrm{~cm}$ which were 
on par with each other. It was followed by treatments $T_{7}$ and $T_{3}$ recorded a plant height of 45.1 and $44.5 \mathrm{~cm}$ which were statistically on par. The treatment $T_{2}$ recorded a plant height of $39.6 \mathrm{~cm}$ at harvest (Fig. 1).

\section{Number of leaves plant $^{-1}$}

The treatment $T_{1}$ recorded the lowest number of leaves plant ${ }^{-1}$ of 9.20 and the treatment $T_{10}$ recorded the highest number of leaves plant ${ }^{-1}$ 21.10. However the treatment $\mathrm{T}_{6}$ which recorded 20.96was on par with treatment $T_{10}$. The treatments $T_{9}$ and $T_{5}$ recorded number of leaves plant ${ }^{-1}$ of 19.23 and 18.96 which were found to be statistically similar. Further the treatments $\mathrm{T}_{8}$ and $\mathrm{T}_{4}$ recorded number of leaves plant ${ }^{-1}$ of 17.39 and 17.22 which were on par with each other. It was followed by treatments $T_{7}$ and $T_{3}$ recorded a number of leaves plant ${ }^{-1}$ of 15.69 and 15.47 which were statistically on par. The treatment $\mathrm{T}_{2}$ recorded a number of leaves plant $^{-1}$ of 13.69 at 30 DAS. The treatment $T_{1}$ recorded the lowest number of leaves plant ${ }^{-1}$ of 12.00 and the treatment $\mathrm{T}_{10}$ recorded the highest number of leaves plant ${ }^{-1}$ of 24.40 . However the treatment $\mathrm{T}_{6}$ which recorded 24.26 was on par with treatment $\mathrm{T}_{10}$. The treatments $\mathrm{T}_{9}$ and $\mathrm{T}_{5}$ recorded number of leaves plant ${ }^{-1}$ of 22.45 and 22.17 which were found to be statistically similar. Further the treatments $\mathrm{T}_{8}$ and $\mathrm{T}_{4}$ recorded number of leaves plant ${ }^{-1} 20.54$ and 20.36 of which were on par with each other. It was followed by treatments $T_{7}$ and $T_{3}$ recorded a number of leaves plant ${ }^{-1}$ of 18.77 and 18.54 which were statistically on par. The treatment $\mathrm{T}_{2}$ recorded a number of leaves plant $^{-1}$ of 16.68 at $45 \mathrm{DAS}$. The treatment $\mathrm{T}_{1}$ recorded the lowest number of leaves plant ${ }^{-1}$ of 13.40 and the treatment $\mathrm{T}_{10}$ recorded the highest number of leaves of plant ${ }^{-1} 28.00$. However the treatment $\mathrm{T}_{6}$ which recorded 27.83 was on par with treatment $T_{10}$. The treatments $\mathrm{T}_{9}$ and $\mathrm{T}_{5}$ recorded number of leaves plant ${ }^{-1}$ of 25.71 and 25.37 which were found to be statistically similar. Further the treatments $\mathrm{T}_{8}$ and $\mathrm{T}_{4}$ recorded number of leaves plant ${ }^{-1}$ of 23.45 and 23.24 which were on par with each other. It was followed by treatments $T_{7}$ and $T_{3}$ recorded a number of leaves plant ${ }^{-1}$ of 21.37 and 21.10 which were statistically on par. The treatment $\mathrm{T}_{2}$ recorded a number of leaves plant ${ }^{-1}$ of 18.91 at harvest (Fig. 5).

\section{Number of branches plant ${ }^{-1}$}

Usage of potassium in the form of MOP and SOP resulted in significant increase in number of branches plant ${ }^{-1}$. The treatment $T_{1}$ recorded the lowest number of branches plant ${ }^{-}$ ${ }^{1}$ of3.10 and the treatment $\mathrm{T}_{10}$ recorded the highest number of branches plant ${ }^{-1} 6.90$. However the treatment $\mathrm{T}_{6}$ which recorded 6.86 was on par with treatment $\mathrm{T}_{10}$. The treatments $\mathrm{T}_{9}$ and $\mathrm{T}_{5}$ recordednumber of branches plant ${ }^{-1}$ of 6.30and 6.22whichwere found to be statistically similar. Further the treatments $\mathrm{T}_{8}$ and $\mathrm{T}_{4}$ recorded number of branches plant ${ }^{-1}$ of 5.72 and 5.66 which were on par with each other. It was followed by treatments $\mathrm{T}_{7}$ and $\mathrm{T}_{3}$ recorded 5.17 and 5.10 number of branches plant ${ }^{-1}$ which were statistically on par. The treatment $\mathrm{T}_{2}$ recorded 4.53 number of branches plant ${ }^{-1}$ at 30 DAS. The treatment $T_{1}$ recorded the lowest number of branches plant ${ }^{-1}$ of 4.90 and the treatment $\mathrm{T}_{10}$ recorded the highest number of branches plant $^{-1}$ of 8.80. However the treatment $T_{6}$ which recorded 8.76 was on par with treatment $\mathrm{T}_{10}$. The treatments $\mathrm{T}_{9}$ and $\mathrm{T}_{5}$ recorded number of branches plant ${ }^{-1}$ of 8.19 and 8.10 which were found to be statistically similar. Further the treatments $\mathrm{T}_{8}$ and $\mathrm{T}_{4}$ recorded 7.59 and 7.53 number of branches plant $^{-1}$ which was on par with each other. It was followed by treatments $T_{7}$ and $T_{3}$ which recorded a number of branches plant ${ }^{-1}$ of 7.03 and 6.96. The treatments $T_{7}$ and $T_{3}$ were statistically on par with each other. The treatment $\mathrm{T}_{2}$ recorded a number of branches 
plant $^{-1}$ of 6.37 at 45 DAS. Application of increased levels of potassium in the form of MOP and SOP resulted in significant increase in number of branches plant ${ }^{-1}$. The treatment $\mathrm{T}_{1}$ recorded the lowest number of branches plant $^{-1}$ of 5.10 and the treatment $\mathrm{T}_{10}$ recorded the highest number of branches of plant ${ }^{-1}$ 10.20. However the treatment $T_{6}$ which recorded 10.14 was on par with treatment $T_{10}$. The treatments $T_{9}$ and $T_{5}$ recorded number of branches plant ${ }^{-1}$ of 9.40 and 9.28 which were found to be statistically similar. Further the treatments $\mathrm{T}_{8}$ and $\mathrm{T}_{4}$ recorded number of branches plant ${ }^{-1}$ of8.61 and 8.54 which were on par with each other. It was followed by treatments $T_{7}$ and $T_{3}$ recorded a number of branches plant $^{-1}$ of 7.88 and 7.79 which were statistically on par. The treatment $\mathrm{T}_{2}$ recorded a number of branches plant ${ }^{-1}$ of 7.02 at harvest (Fig. 3).

\section{Leaf area index (LAI)}

The treatment $T_{1}$ recorded the lowest leaf area index of 1.30 and the treatment $\mathrm{T}_{10}$ recorded the highest leaf area index 1.76. However the treatment $\mathrm{T}_{6}$ which recorded 1.75 was on par with treatment $T_{10}$. The treatments $T_{9}$ and $T_{5}$ recorded leaf area index of 1.69 and 1.68 which were found to be statistically similar. Further the treatments $T_{8}$ and $T_{4}$ recorded leaf area index of 1.62 and 1.61 which were on par with each other. It was followed by treatments $\mathrm{T}_{7}$ and $\mathrm{T}_{3}$ recorded a leaf area index of 1.55 and 1.54 which were statistically on par with each other. The treatment $\mathrm{T}_{2}$ recorded a leaf area index of 1.47 at $30 \mathrm{DAS}$. The treatment $\mathrm{T}_{1}$ recorded the lowest leaf area index 1.65 and the treatment $T_{10}$ recorded the highest leaf area index of 2.16. However the treatment $\mathrm{T}_{6}$ which recorded 2.15 was on par with treatment $T_{10}$. The treatments $T_{9}$ and $T_{5}$ recorded leaf area index of 2.08 and 2.07 which were found to be statistically similar. Further the treatments $\mathrm{T}_{8}$ and $\mathrm{T}_{4}$ recorded leaf area index 2.00 and 1.99 of which were on par with each other. It was followed by treatments
$\mathrm{T}_{7}$ and $\mathrm{T}_{3}$ which recorded a leaf area index of 1.93 and 1.92. The treatments $T_{7}$ and $T_{3}$ were statistically on par. The treatment $\mathrm{T}_{2}$ recorded a leaf area index of 1.84 at 45 DAS. The treatments $\mathrm{T}_{1}$ recorded the lowest leaf area index of 1.90 and the treatment $T_{10}$ recorded the highest leaf area index of 2.42. However the treatment $\mathrm{T}_{6}$ which recorded 2.41 was on par with treatment $T_{10}$. The treatments $T_{9}$ and $\mathrm{T}_{5}$ recorded leaf area index of 2.34 and 2.33 which were found to be statistically similar. Further the treatments $\mathrm{T}_{8}$ and $\mathrm{T}_{4}$ recorded leaf area index of 2.26 and 2.25 which were on par with each other. It was followed by treatments $\mathrm{T}_{7}$ and $\mathrm{T}_{3}$ recorded a leaf area index of 2.18 and 2.17 which were statistically on par. The treatment $\mathrm{T}_{2}$ recorded a leaf area index of 2.10 (Fig. 7).

\section{Chlorophyll content ( $\left.\mathrm{mg} \mathrm{g}^{-\mathbf{1}}\right)$}

Increased levels of potassium in the form of MOP and SOP resulted in significant increase in chlorophyll a and chlorophyll b. The treatment $T_{1}$ recorded the lowest chlorophyll $\mathrm{a}$ and chlorophyll $\mathrm{b}$ of 0.27 and $0.25 \mathrm{mg} \mathrm{g}^{-1}$ and the treatment $T_{10}$ recorded the highest chlorophyll a and chlorophyll $\mathrm{b} 0.51$ and 0.47 $\mathrm{mg} \mathrm{g}^{-1}$. However the treatment $\mathrm{T}_{6}$ which recorded 0.51 and $0.47 \mathrm{mg} \mathrm{g}^{-1}$ was on par with treatment $T_{10}$. The treatments $T_{9}$ and $T_{5}$ recorded chlorophyll a and chlorophyll $\mathrm{b}$ of $0.47,0.44 \mathrm{mg} \mathrm{g}^{-1}$ and $0.47,0.43 \mathrm{mg} \mathrm{g}^{-1}$ which were found to be statistically similar. Further the treatments $T_{8}$ and $T_{4}$ recorded chlorophyll $\mathrm{a}$ and chlorophyll $\mathrm{b}$ of $0.44,0.40 \mathrm{mg} \mathrm{g}^{-1}$ and $0.43,0.40 \mathrm{mg} \mathrm{g}^{-1}$ which were on par with each other. It was followed by treatments $\mathrm{T}_{7}$ and $\mathrm{T}_{3}$ recorded a chlorophyll a and chlorophyll $\mathrm{b}$ of $0.40,0.37 \mathrm{mg} \mathrm{g}^{-1}$ and $0.39,0.37 \mathrm{mg} \mathrm{g}^{-1}$ and which were statistically on par. The treatment $\mathrm{T}_{2}$ recorded a chlorophyll a and chlorophyll b of 0.36 and $0.33 \mathrm{mg} \mathrm{g}^{-1}$ at 30 DAS. The treatment $\mathrm{T}_{1}$ recorded the lowest chlorophyll $\mathrm{a}$ and chlorophyll $\mathrm{b} 0.46$ and $0.45 \mathrm{mg} \mathrm{g}^{-1}$ and the treatment $\mathrm{T}_{10}$ recorded the highest chlorophyll a and chlorophyll b of 0.89 and 
$0.88 \mathrm{mg} \mathrm{g}^{-1}$. However the treatment $\mathrm{T}_{6}$ which recorded 0.89 and $0.88 \mathrm{mg} \mathrm{g}^{-1}$ was on par with treatment $\mathrm{T}_{10}$. The treatments $\mathrm{T}_{9}$ and $\mathrm{T}_{5}$ recorded chlorophyll $\mathrm{a}$ and chlorophyll $\mathrm{b}$ of $0.82,0.81 \mathrm{mg} \mathrm{g}^{-1}$ and $0.81,0.80 \mathrm{mg} \mathrm{g}^{-1}$ which were found to be statistically similar. Further the treatments $\mathrm{T}_{8}$ and $\mathrm{T}_{4}$ recorded chlorophyll $a$ and chlorophyll $b$ readings $0.76,0.74 \mathrm{mg} \mathrm{g}^{-1}$ and $0.75,0.74 \mathrm{mg} \mathrm{g}^{-1}$ which were on par with each other. It was followed by treatments $T_{7}$ and $\mathrm{T}_{3}$ which recorded a chlorophyll $\mathrm{a}$ and chlorophyll b readings of $0.69,0.68 \mathrm{mg} \mathrm{g}^{-1}$ and $0.69,0.67 \mathrm{mg}^{-1}$ respectively. The treatments $T_{7}$ and $T_{3}$ were statistically similar. The treatment $T_{2}$ recorded a chlorophyll a and chlorophyll $b$ of 0.62 and $0.61 \mathrm{mg} \mathrm{g}^{-1}$. Significant differences in total chlorophyll content were observed due to the application of potassium (MOP and SOP) in different treatments. The treatment $\mathrm{T}_{1}$ recorded the lowest total chlorophyll 0.52 and $0.91 \mathrm{mg} \mathrm{g}^{-1}$ and the treatment $\mathrm{T}_{10}$ recorded the highest total chlorophyll of 0.98 and $1.77 \mathrm{mg} \mathrm{g}^{-1}$. However the treatment $\mathrm{T}_{6}$ which recorded 0.97 and $1.76 \mathrm{mg} \mathrm{g}^{-1}$ was on par with treatment $\mathrm{T}_{10}$. The treatments $\mathrm{T}_{9}$ and $\mathrm{T}_{5}$ recorded total chlorophyll of $0.91,1.63 \mathrm{mg} \mathrm{g}^{-1}$ and $0.90,1.62 \mathrm{mg} \mathrm{g}^{-1}$ which were found to be statistically similar. Further the treatments $\mathrm{T}_{8}$ and $\mathrm{T}_{4}$ recorded total chlorophyll readings $0.84,1.50 \mathrm{mg} \mathrm{g}^{-1}$ and $0.83,1.49 \mathrm{mg} \mathrm{g}^{-1}$ which were on par with each other. It was followed by treatments $T_{7}$ and $T_{3}$ which recorded total chlorophyll readings of $0.77,1.38 \mathrm{mg} \mathrm{g}^{-1}$ and $0.76,1.36 \mathrm{mg} \mathrm{g}^{-1}$ respectively. The treatments $\mathrm{T}_{7}$ and $\mathrm{T}_{3}$ were statistically on par. The treatment $\mathrm{T}_{2}$ recorded total chlorophyll of $0.69,1.23 \mathrm{mg} \mathrm{g}^{-1}$ at 30, 45 DAS respectively.

\section{Field experiment}

\section{Plant height (cm)}

The treatment $T_{1}$ recorded the lowest plant height of $11.2 \mathrm{~cm}$ and the treatment $\mathrm{T}_{10}$ recorded the highest plant height of $35.2 \mathrm{~cm}$.
However the treatment $\mathrm{T}_{6}$ which recorded 34.9 $\mathrm{cm}$ was on par with treatment $\mathrm{T}_{10}$. The treatments $\mathrm{T}_{9}$ and $\mathrm{T}_{5}$ recorded plant height of 31.4 and $30.8 \mathrm{~cm}$ which were found to be statistically similar. Further the treatments $\mathrm{T}_{8}$ and $\mathrm{T}_{4}$ recorded plant height of 27.7 and 27.3 $\mathrm{cm}$ which were on par with each other. It was followed by treatments $\mathrm{T}_{7}$ and $\mathrm{T}_{3}$ recorded a plant height of 24.3 and $23.8 \mathrm{~cm}$ which were statistically on par. The treatment $\mathrm{T}_{2}$ recorded a plant height of $20.2 \mathrm{~cm}$ at $30 \mathrm{DAS}$.

Application of increased levels of potassium in the form of MOP and SOP resulted in significant increase in plant height. The treatment $T_{1}$ recorded the lowest plant height of $16.6 \mathrm{~cm}$ and the treatment $T_{10}$ recorded the highest plant height of $46.0 \mathrm{~cm}$. However the treatment $\mathrm{T}_{6}$ which recorded $45.6 \mathrm{~cm}$ was on par with treatment $T_{10}$. The treatments $T_{9}$ and $\mathrm{T}_{5}$ recorded plant height of 41.3 and $40.7 \mathrm{~cm}$ which were found to be statistically similar. Further the treatments $\mathrm{T}_{8}$ and $\mathrm{T}_{4}$ recorded plant height of 36.8 and $36.4 \mathrm{~cm}$ which were on par with each other. It was followed by treatments $\mathrm{T}_{7}$ and $\mathrm{T}_{3}$ recorded a plant height of 32.6 and $32.1 \mathrm{~cm}$ which were statistically on par. The treatment $T_{2}$ recorded a plant height of $27.6 \mathrm{~cm}$ at 45 DAS. Potassium has been used in the form of MOP and SOP resulted in significant increase in plant height. The treatment $\mathrm{T}_{1}$ recorded the lowest plant height of $28.8 \mathrm{~cm}$ and the treatment $\mathrm{T}_{10}$ recorded the highest plant height of $60.8 \mathrm{~cm}$. However the treatment $\mathrm{T}_{6}$ which recorded $60.4 \mathrm{~cm}$ was on par with treatment $T_{10}$. The treatments $T_{9}$ and $\mathrm{T}_{5}$ recorded plant height of 55.7 and $55.0 \mathrm{~cm}$ which were found to be statistically similar. Further the treatments $\mathrm{T}_{8}$ and $\mathrm{T}_{4}$ recorded plant height of50.8 and $50.3 \mathrm{~cm}$ which were on par with each other. It was followed by treatments $T_{7}$ and $T_{3}$ recorded a plant height of 46.2 and $45.6 \mathrm{~cm}$ which were statistically on par. The treatment $T_{2}$ recorded a plant height of $40.8 \mathrm{~cm}$ at harvest (Fig. 2). 


\section{Number of branches plant ${ }^{-1}$}

The treatment $\mathrm{T}_{1}$ recorded the lowest number of branches plant ${ }^{-1}$ of 3.8 and the treatment $\mathrm{T}_{10}$ recorded the highest number of branches plant $^{-1}$ 7.40. However the treatment $T_{6}$ which recorded 7.36 was on par with treatment $T_{10}$. The treatments $\mathrm{T}_{9}$ and $\mathrm{T}_{5}$ recorded number of branches plant ${ }^{-1}$ of 6.83 and 6.75 which were found to be statistically similar. Further the treatments $T_{8}$ and $T_{4}$ recorded number of branches plant ${ }^{-1}$ of 6.28 and 6.23 which were on par with each other. It was followed by treatments $T_{7}$ and $T_{3}$ recorded a number of branches plant ${ }^{-1}$ of 5.76 and 5.70 which were statistically on par. The treatment $\mathrm{T}_{2}$ recorded a number of branches plant ${ }^{-1}$ of 5.16 at 30 DAS. Increased levels of potassium in the form of MOP and SOP usage resulted in significant increase in number of branches plant ${ }^{-1}$. The treatment $T_{1}$ recorded the lowest number of branches plant ${ }^{-1}$ of 5.60 and the treatment $\mathrm{T}_{10}$ recorded the highest number of branches plant $^{-1}$ of 9.80. However the treatment $T_{6}$ which recorded 9.75 was on par with treatment $T_{10}$. The treatments $T_{9}$ and $T_{5}$ recorded number of branches plant ${ }^{-1}$ of 9.14 and 9.04 which were found to be statistically similar. Further the treatments $\mathrm{T}_{8}$ and $\mathrm{T}_{4}$ recorded number of branches plant ${ }^{-1}$ of 8.49 and 8.43 which were on par with each other. It was followed by treatments $\mathrm{T}_{7}$ and $\mathrm{T}_{3}$ recorded a number of branches plant ${ }^{-1}$ of 7.89 and 7.81 which were statistically on par. The treatment $\mathrm{T}_{2}$ recorded a number of branches plant $^{-1}$ of $7.18 \mathrm{~cm}$ at 45 DAS. The treatment $\mathrm{T}_{1}$ recorded the lowest number of branches plant $^{-1}$ of 6.10 and the treatment $T_{10}$ recorded the highest number of branches of plant ${ }^{-1}$ 12.00. However the treatment $\mathrm{T}_{6}$ which recorded $11.93 \mathrm{~cm}$ was on par with treatment $\mathrm{T}_{10}$. The treatments $\mathrm{T}_{9}$ and $\mathrm{T}_{5}$ recorded number of branches plant ${ }^{-1}$ of 11.07 and 10.94 which were found to be statistically similar. Further the treatments $T_{8}$ and $T_{4}$ recorded number of branches plant ${ }^{-1}$ of 10.16 and 10.08 which were on par with each other. It was followed by treatments $T_{7}$ and $T_{3}$ recorded a number of branches plant ${ }^{-1}$ of 9.32 and 9.21 which were statistically on par. The treatment $\mathrm{T}_{2}$ recorded a number of branches plant ${ }^{-1}$ of 8.33 at harvest (Fig. 4).

\section{Leaf area index (LAI)}

The treatment $\mathrm{T}_{1}$ recorded the lowest leaf area index of 1.00 and the treatment $\mathrm{T}_{10}$ recorded the highest leaf area index 1.90. However the treatment $\mathrm{T}_{6}$ which recorded 1.89 was on par with treatment $\mathrm{T}_{10}$. The treatments $\mathrm{T}_{9}$ and $\mathrm{T}_{5}$ recorded leaf area index of 1.76 and 1.74 which were found to be statistically similar. Further the treatments $T_{8}$ and $T_{4}$ recorded leaf area index of 1.62 and 1.61 which were on par with each other. It was followed by treatments $\mathrm{T}_{7}$ and $\mathrm{T}_{3}$ recorded a leaf area index of 1.49 and 1.47 which were statistically on par. The treatment $\mathrm{T}_{2}$ recorded a leaf area index of 1.34 at $30 \mathrm{DAS}$. The treatment $\mathrm{T}_{1}$ recorded the lowest leaf area index 1.60 and the treatment $\mathrm{T}_{10}$ recorded the highest leaf area index of 2.24. However the treatment $\mathrm{T}_{6}$ which recorded 2.23 was on par with treatment $\mathrm{T}_{10}$ (Fig. 8).

The treatments $T_{9}$ and $T_{5}$ recorded leaf area index of 2.14 and 2.12 which were found to be statistically similar. Further the treatments $\mathrm{T}_{8}$ and $\mathrm{T}_{4}$ recorded leaf area index 2.04 and 2.03 of which were on par with each other. It was followed by treatments $\mathrm{T}_{7}$ and $\mathrm{T}_{3}$ recorded a leaf area index of 1.95 and 1.94 and which were statistically on par. The treatment $\mathrm{T}_{2}$ recorded a leaf area index of 1.84 at 45 DAS. The treatments $\mathrm{T}_{1}$ recorded the lowest leaf area index of 1.90 and the treatment $\mathrm{T}_{10}$ recorded the highest leaf area index of 2.60. However the treatment $\mathrm{T}_{6}$ which recorded 2.59 was on par with treatment $\mathrm{T}_{10}$. The treatments $\mathrm{T}_{9}$ and $\mathrm{T}_{5}$ recorded leaf area index of 2.49 and 2.47 which were found to be statistically similar. 
Further the treatments $\mathrm{T}_{8}$ and $\mathrm{T}_{4}$ recorded leaf area index of 2.38 and 2.37 which were on par with each other. It was followed by treatments $\mathrm{T}_{7}$ and $\mathrm{T}_{3}$ recorded a leaf area index of 2.28 and 2.27 which were statistically on par. The treatment $\mathrm{T}_{2}$ recorded a leaf area index of 2.16 at harvest.

\section{Total chlorophyll ( $\left.\mathrm{mg} \mathrm{g}^{-1}\right)$}

The treatment $T_{1}$ recorded the lowest chlorophyll $\mathrm{a}$ and chlorophyll $\mathrm{b}$ of 0.28 and $0.25 \mathrm{mg} \mathrm{g}^{-1}$ and the treatment $\mathrm{T}_{10}$ recorded the highest chlorophyll a and chlorophyll b 0.49 and $0.46 \mathrm{mg} \mathrm{g}^{-1}$. However the treatment $\mathrm{T}_{6}$ which recorded 0.49 and $0.46 \mathrm{mg} \mathrm{g}^{-1}$ was on par with treatment $T_{10}$. The treatments $T_{9}$ and $\mathrm{T}_{5}$ recorded chlorophyll $\mathrm{a}$ and chlorophyll $\mathrm{b}$ of $0.46,0.45 \mathrm{mg} \mathrm{g}^{-1}$ and $0.45,0.42 \mathrm{mg} \mathrm{g}^{-1}$ which were found to be statistically similar. Further the treatments $\mathrm{T}_{8}$ and $\mathrm{T}_{4}$ recorded chlorophyll a and chlorophyll b of $0.42,0.39$ $\mathrm{mg} \mathrm{g}^{-1}$ and $0.42,0.39 \mathrm{mg} \mathrm{g}^{-1}$ which were on par with each other. It was followed by treatments $\mathrm{T}_{7}$ and $\mathrm{T}_{3}$ which recorded a chlorophyll a and chlorophyll $b$ of $0.39,0.36$ $\mathrm{mg} \mathrm{g}^{-1}$ and $0.39,0.36 \mathrm{mg} \mathrm{g}^{-1}$. The treatments $\mathrm{T}_{7}$ and $\mathrm{T}_{3}$ were statistically on par. The treatment $\mathrm{T}_{2}$ recorded a chlorophyll a and chlorophyll b of 0.36 and $0.33 \mathrm{mg} \mathrm{g}^{-1}$ at 30 DAS. Significant increase in chlorophyll a and chlorophyll $b$ was observed due to potassium application. The treatment $T_{1}$ recorded the lowest chlorophyll $\mathrm{a}$ and chlorophyll $\mathrm{b} 0.47$ and $0.45 \mathrm{mg} \mathrm{g}^{-1}$ and the treatment $\mathrm{T}_{10}$ recorded the highest chlorophyll $\mathrm{a}$ and chlorophyll $\mathrm{b}$ of 0.89 and $0.84 \mathrm{mg} \mathrm{g}^{-1}$. However the treatment $\mathrm{T}_{6}$ which recorded 0.90 and 0.89 was on par with treatment $\mathrm{T}_{10}$. The treatments $\mathrm{T}_{9}$ and $\mathrm{T}_{5}$ recorded chlorophyll $\mathrm{a}$ and chlorophyll $\mathrm{b}$ of $0.82,0.78$ $\mathrm{mg} \mathrm{g}^{-1}$ and $0.81,0.77 \mathrm{mg} \mathrm{g}^{-1}$ which were found to be statistically similar. Further the treatments $T_{8}$ and $T_{4}$ recorded chlorophyll a and chlorophyll $\mathrm{b} 0.76,0.72 \mathrm{mg} \mathrm{g}^{-1}$ and 0.75 , $0.71 \mathrm{mg} \mathrm{g}^{-1}$ of which were on par with each other. It was followed by treatments $T_{7}$ and $T_{3}$ recorded a chlorophyll a and chlorophyll b of $0.70,0.66 \mathrm{mg} \mathrm{g}^{-1}$ and $0.69,0.66 \mathrm{mg} \mathrm{g}^{-1}$ and which were statistically on par. The treatment $\mathrm{T}_{2}$ recorded a chlorophyll a and chlorophyll $\mathrm{b}$ of 0.63 and $0.60 \mathrm{mg} \mathrm{g}^{-1}$ at 45 DAS. Significant differences in total chlorophyll content were observed due to the application of potassium (MOP and SOP) in different treatments. The treatment $\mathrm{T}_{1}$ recorded the lowest total chlorophyll 0.54 and $0.93 \mathrm{mg} \mathrm{g}^{-1}$ and the treatment $T_{10}$ recorded the highest total chlorophyll of 0.96 and $1.80 \mathrm{mg} \mathrm{g}^{-1}$. However the treatment $\mathrm{T}_{6}$ which recorded 0.96 and $1.79 \mathrm{mg} \mathrm{g}^{-1}$ was on par with treatment $\mathrm{T}_{10}$. The treatments $\mathrm{T}_{9}$ and $\mathrm{T}_{5}$ recorded chlorophyll of $0.89,1.66 \mathrm{mg} \mathrm{g}^{-1}$ and $0.88,1.64 \mathrm{mg} \mathrm{g}^{-1}$ which were found to be statistically similar. Further the treatments $\mathrm{T}_{8}$ and $\mathrm{T}_{4}$ recorded total chlorophyll readings $0.83,1.53 \mathrm{mg} \mathrm{g}^{-1}$ and $0.82,1.52 \mathrm{mg} \mathrm{g}^{-1}$ were on par with each other. It was followed by treatments $T_{7}$ and $T_{3}$ which recorded total chlorophyll readings of $0.77,1.40 \mathrm{mg} \mathrm{g}^{-1}$ and $0.76,1.39 \mathrm{mg} \mathrm{g}^{-1}$ respectively. The treatments $\mathrm{T}_{7}$ and $\mathrm{T}_{3}$ were statistically on par. The treatment $\mathrm{T}_{2}$ recorded a total chlorophyll of $0.70,1.26 \mathrm{mg} \mathrm{g}^{-1}$ at 30,45 DAS respectively.

\section{Number of nodules plant ${ }^{-1}$}

Application of increased levels of potassium in the form of MOP and SOP resulted in significant increase in number of nodules plant $^{-1}$. The treatment $T_{1}$ recorded the lowest number of nodules plant ${ }^{-1}$ of 13.80 and the treatment $T_{10}$ recorded the highest number of nodules plant ${ }^{-1}$ of 27.00. However the treatment $\mathrm{T}_{6}$ which recorded 26.85 was on par with treatment $T_{10}$. The treatments $T_{9}$ and $T_{5}$ recorded number of nodules plant ${ }^{-1}$ of 24.93 and 24.62 which were found to be statistically similar. Further the treatments $\mathrm{T}_{8}$ and $\mathrm{T}_{4}$ recorded number of nodulesplant ${ }^{-1}$ of 22.89 and 22.70 which were on par with each other. It was followed by treatments $T_{7}$ and $T_{3}$ recorded a number of nodules plant ${ }^{-1}$ of 21.00 and 20.76 which were statistically on par. The 
treatment $\mathrm{T}_{2}$ recorded a number of nodules plant $^{-1}$ of 18.78 at harvest (Fig. 6).

The application of potassium $40 \mathrm{~kg} \mathrm{ha}^{-1}$ MOP and $40 \mathrm{~kg} \mathrm{ha}^{-1}$ SOP recorded statistically growth parameters such as significant higher plant height, significant higher number of branches per plant, significant higher number of leaves per plant at different growth stages, compared to control and lower doses of muriate of potash and sulphate of potash. Plant height showed an increase with increasing levels of potassium. Plants received more potassium along with nitrogen might have encouraged the vegetative growth. In field experiments the plant height increased due to soil application of SOP produced higher plant height 30, 45 DAS and at harvest. The plant height were recorded (35.2, 46.6 and $60.80 \mathrm{~cm}$ ) which were 68,64 and53\% higher compared to absolute control $(11.2,16.6$ and $28.8 \mathrm{~cm})$. Similarly in pot experiments the plant height increased due to soil application of SOP produced higher plant height 30,45 DAS and at harvest. The plant height were recorded $(33.7,43.6$ and $60.0 \mathrm{~cm})$ which were 67, 66 and 55\% higher compared to absolute control (10.9, 14.6 and $27.3 \mathrm{~cm})$. Potash levels along with uniform dose of nitrogen increased the plant height significantly. Redistribution of resources leading to cell enlargement and cell division (Karivaratharaju and Ramakrishnan, 1985). This increase in plant height under higher $\mathrm{K}$ level was mainly associated with adequacy of nutrients in soil after application and application of potassium fertilizer improves length of stem, branches, pods, seed weight and seed yield. Similar results obtained by Buriro et al., (2015) and Fathima et al., (2001). Kumar et al., (2014) resulted significant increase in plant height with potash application can be attributed to the fact that potash enhances plant vigour and strengthens the stalk. $\mathrm{K}^{+}$is essential for attaining full activity of enzyme which has an impact on numerous physiological processes
(Das, 1999). Some of them are of major relevance for the plant growth and production. These results are also in conformity with Tak et al., (2013).

Potassium fertilizer gave the highest rates of plant height with significance difference from the rest of interactions and that can be explained by availability of the humidity and element of potassium in soils from the beginning of plant growth that led to an increase the speed of photosynthesis and that reflected positively on the plant height. These results are also in conformity with Shahzad et al., (2014) and Mustafa et al., (2016). The number of branches plant ${ }^{-1}$ increased significantly with increased levels of potassium. In field experiment the number of branches plant ${ }^{-1}$ increased due to the soil application of $40 \mathrm{~kg} \mathrm{ha}^{-1}$ SOP produced higher number of branches plant ${ }^{-1}$ at 30, 45 DAS and at harvest (7.40, 9.80 and 12 respectively). The values were 49, 43 and $49 \%$ higher compared to absolute control $(3.80,5.60$ and 6.10 respectively). The pot experiments also followed similar pattern of results. The higher number of branches plant ${ }^{-1}$ recorded at 30DAS, 45 DAS and at harvest were 6.90, 8.80 and 10.20 respectively were 55,44 and $50 \%$ higher compared to absolute control which recorded 3.10, 4.90 and 5.10 respectively. The results of this experiment were in accordance with these Buriro et al., (2015), who noticed with the application of K, the plants grew vigorously to produce more branches plant ${ }^{-1}$. Number of leaves plant $^{-1}$ showed significant increase with increasing level of potassium. In pot culture experiment the number of leaves plant ${ }^{-1}$ increased due to the soil application of $40 \mathrm{~kg} \mathrm{ha}^{-1} \mathrm{SOP}$. The treatment produced higher number of leaves plant $^{-1}$ at 30, 45 DAS and at harvest (21.10, 24.40 and 28.00) which were 56, 51 and $52 \%$ higher compared to absolute control (9.20, 12.00 and 13.40). 
Fig.1 Effect of potassium on plant height $(\mathrm{cm})$ of green gram VBN 2 (Pot culture experiment)

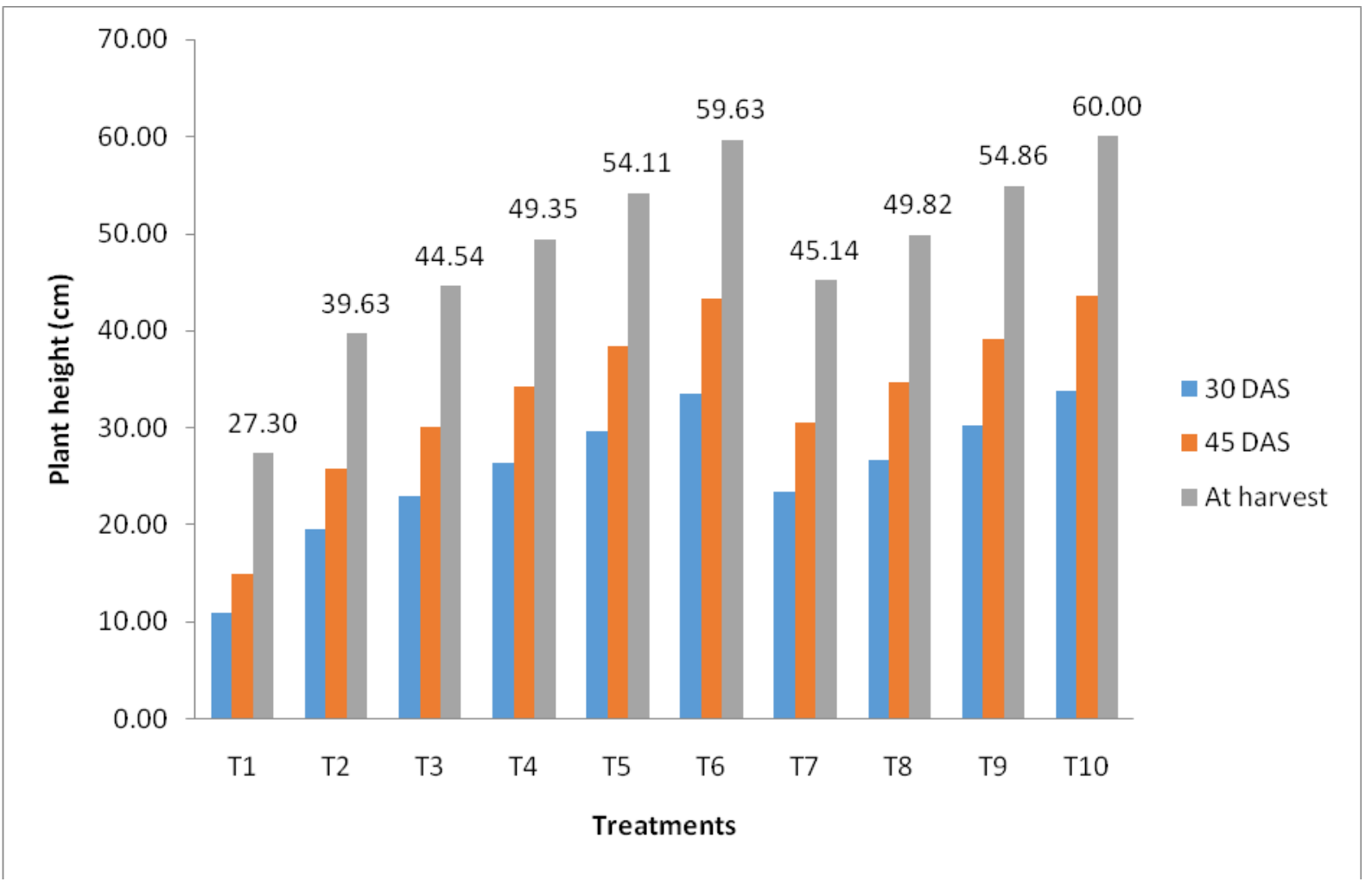

Fig.2 Effect of potassium on plant height $(\mathrm{cm})$ of green gram VBN 2 (Field experiment)




Fig.3 Effect of potassium on number of branches plant-1 of green gram VBN 2 (Pot culture experiment)

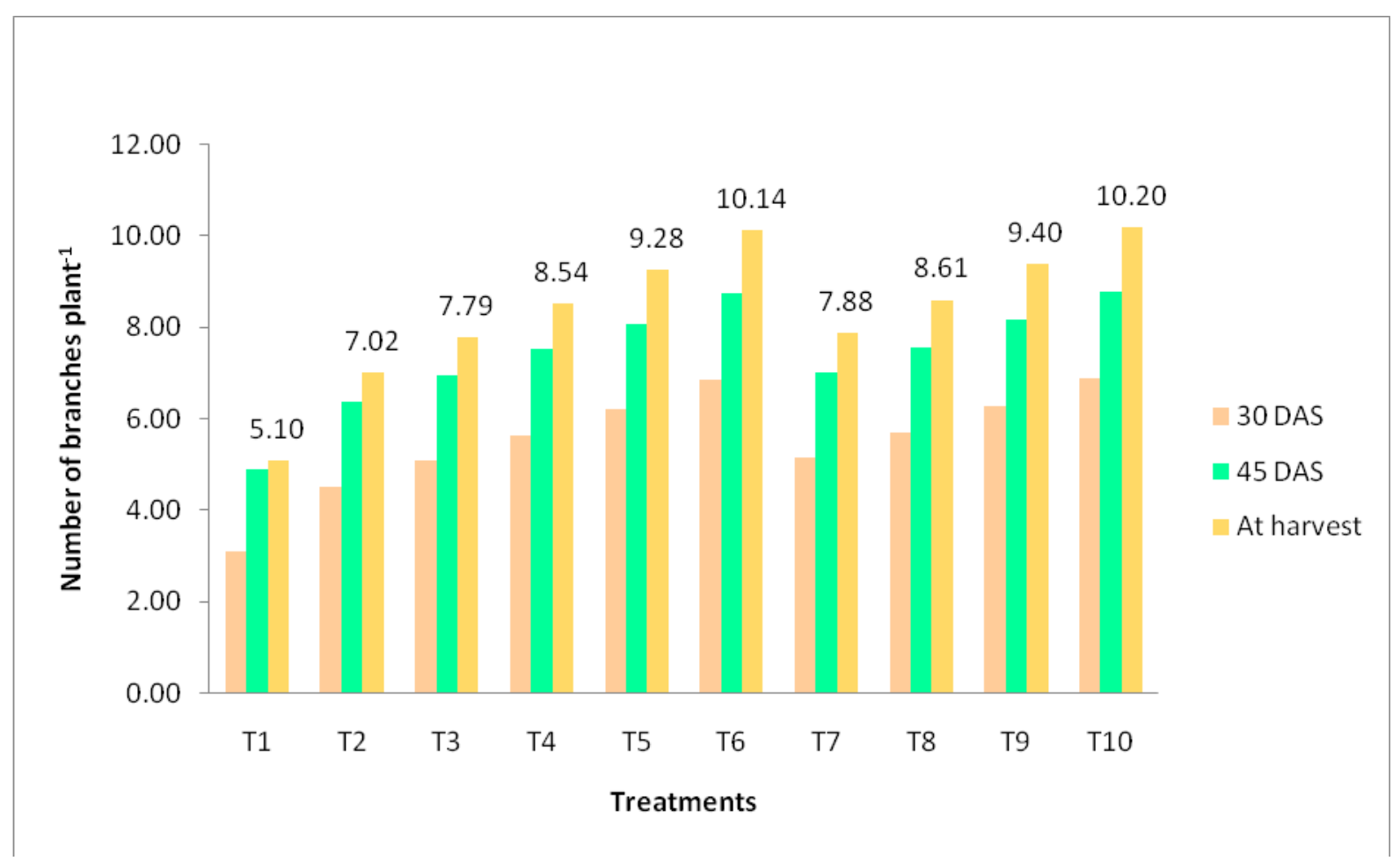

Fig.4 Effect of potassium on number of branches plant-1 of green gram VBN 2 (Field experiment)

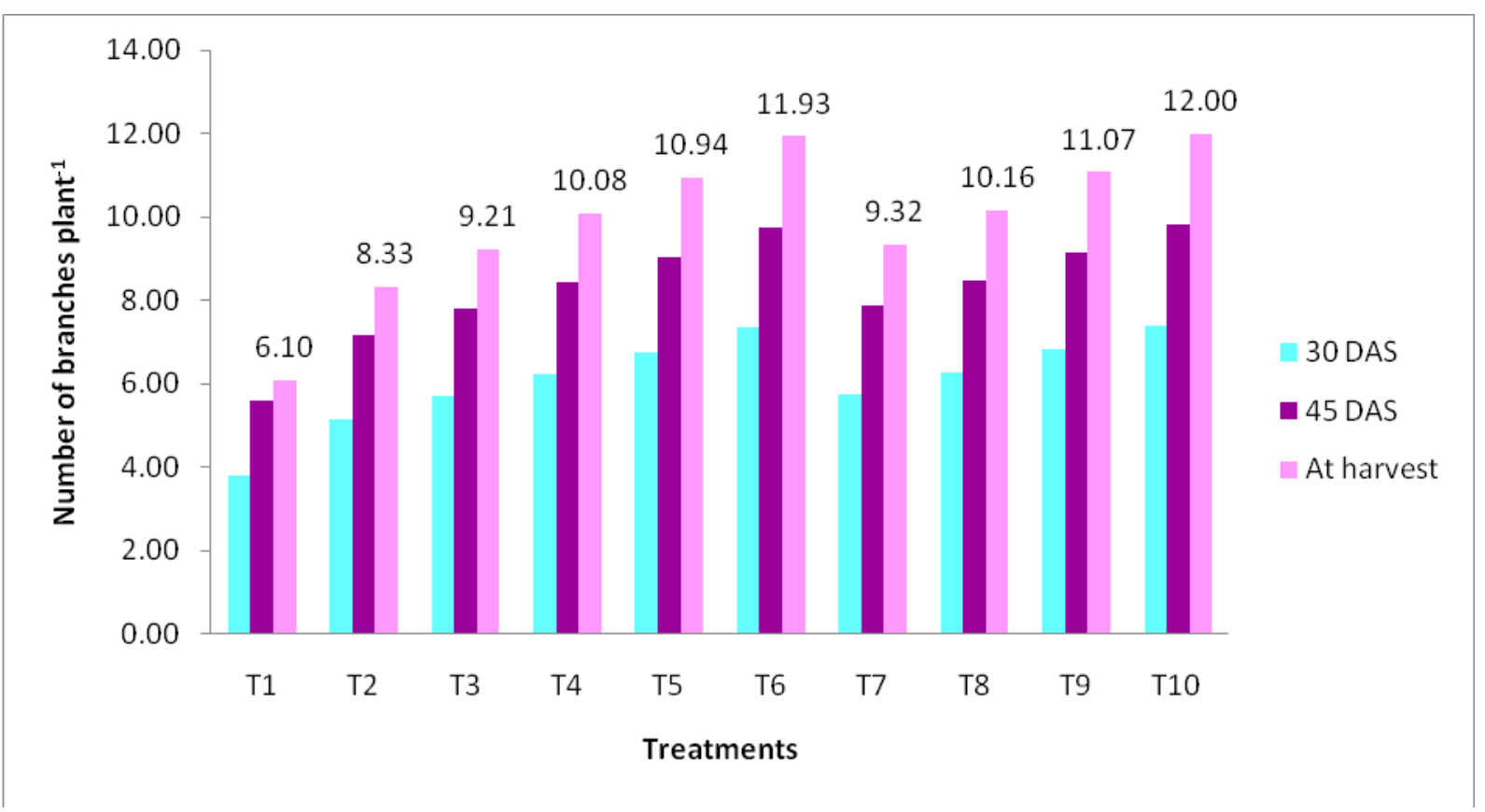


Fig.5 Effect potassium on number of leaves plant ${ }^{-1}$ of green gram VBN 2 (Pot culture experiment)

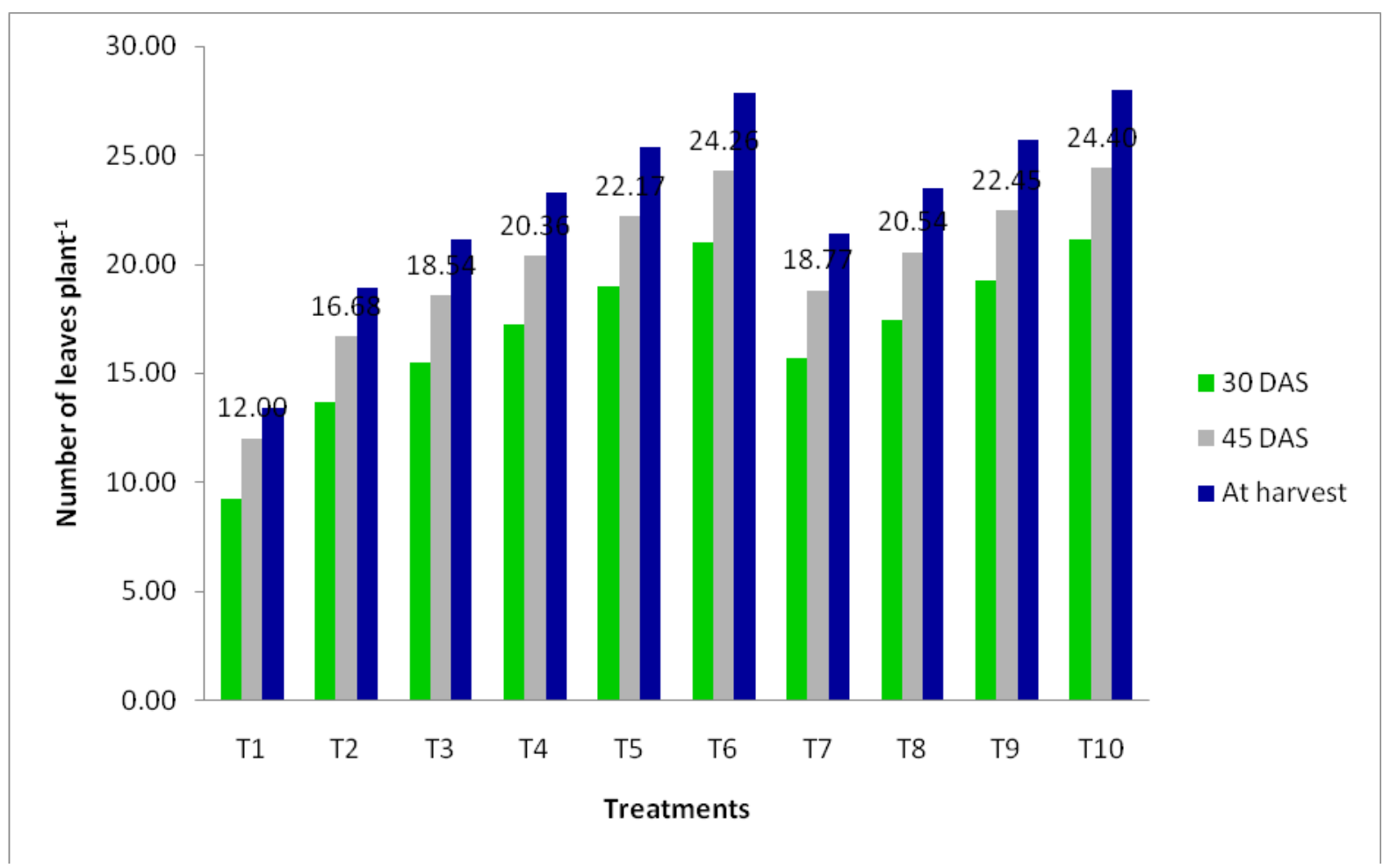

Fig.6 Effect of potassium on number of nodules plant ${ }^{-1}$ of green gram VBN 2 (Field experiment)

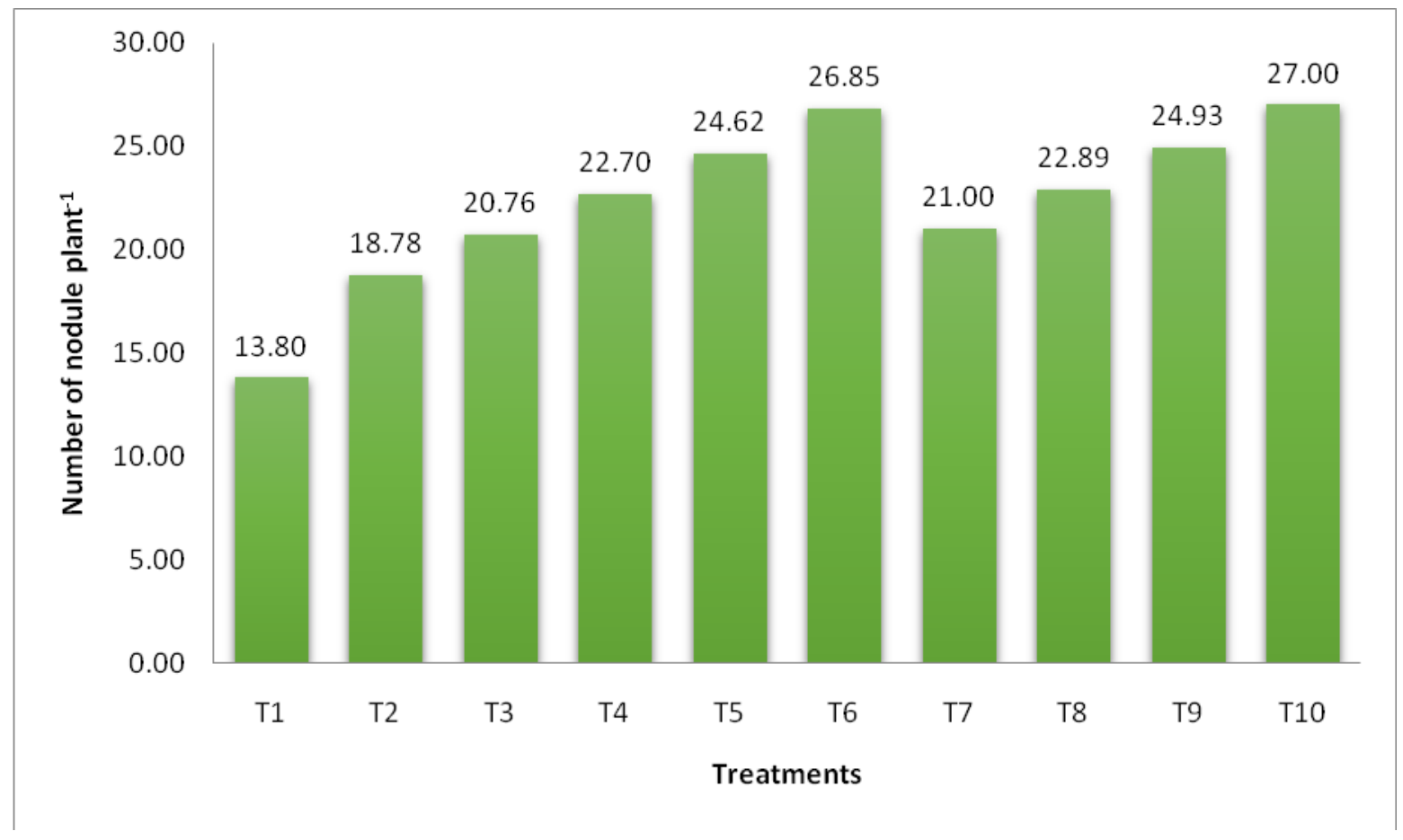


Fig.7 Effect of potassium on leaf area index of greengram at VBN 2 (Pot culture experiment)

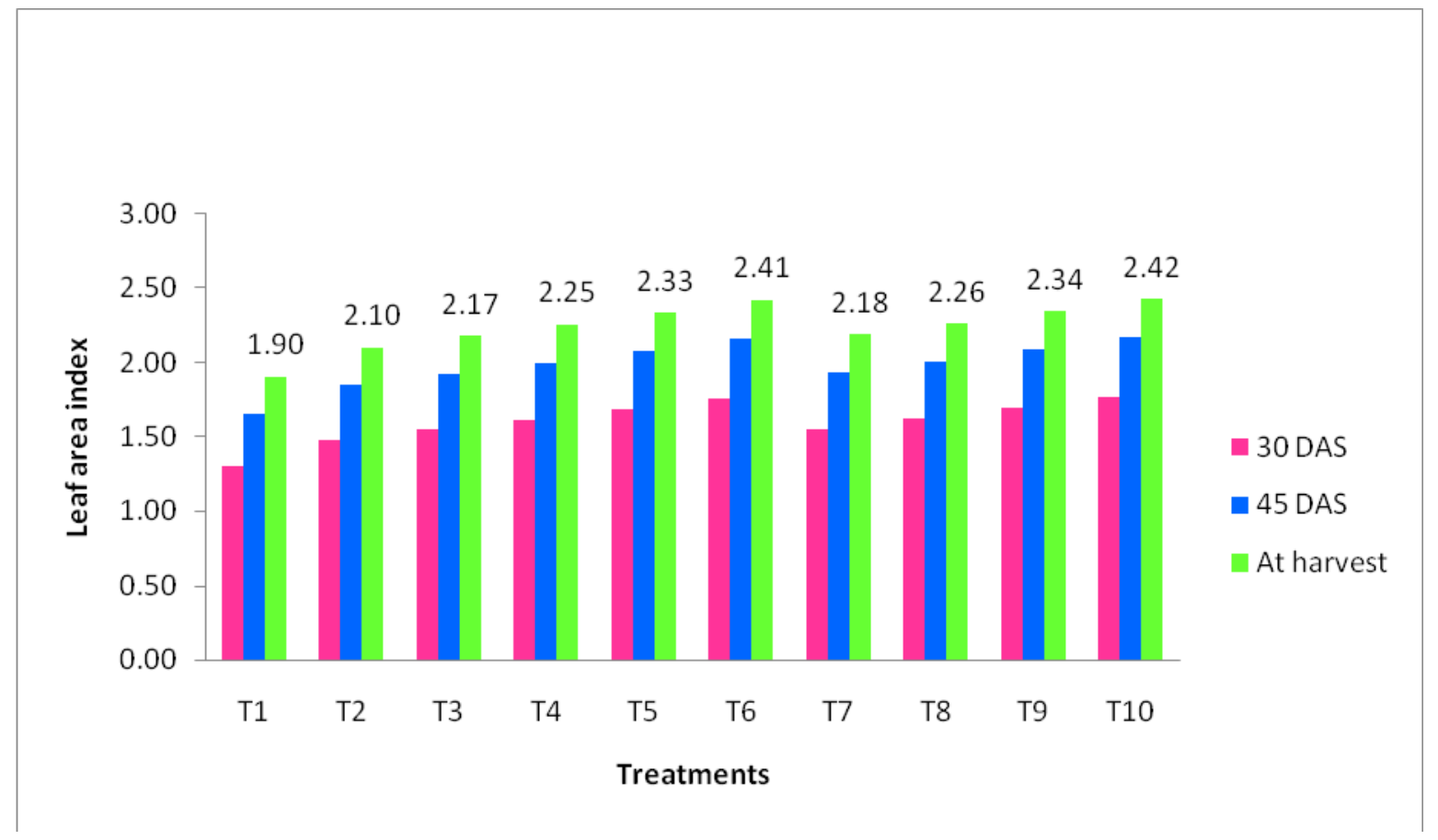

Fig.8 Effect of potassium on leaf area index of green gram VBN 2 (Field experiment)

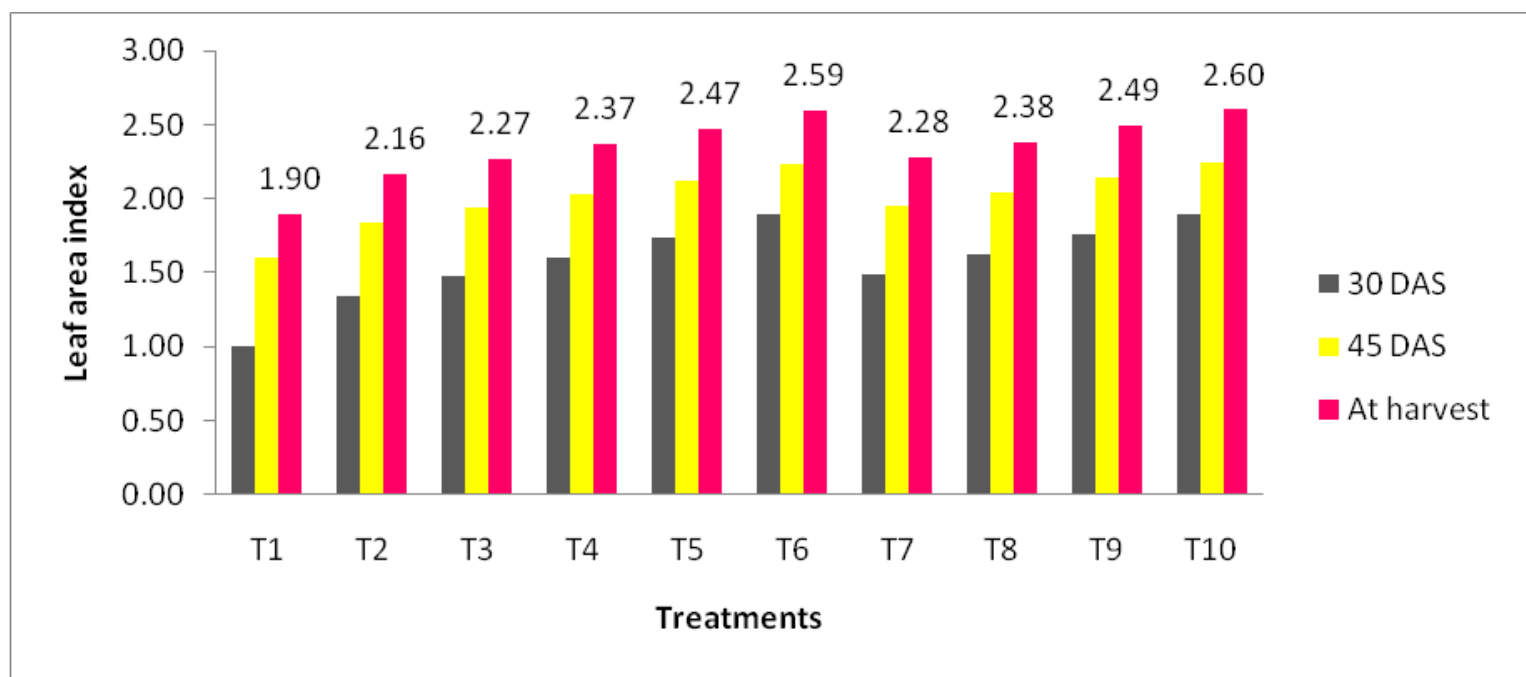

Potassium application increased the were reported by Ali et al., (1996) and availability of nitrogen and phosphorus, which resulted in better more number of branches plant $^{-1}$. Similar findings were reported by Kumar et al., (2014) and Sahai (2004). Highest number of branches may be due to $\mathrm{K}$ application increased the availability of nitrogen and phosphorous. Similar findings

Khairul Mazed et al., (2016). Total Chlorophyll content showed an increase with increasing level of potassium. Chlorophyll content increased due to the soil application of SOP @ $40 \mathrm{Kg} \mathrm{ha}{ }^{-1}$ produced higher chlorophyll content at 30, 45 DAS were recorded $0.96,1.80$ which were 44 and $48 \%$ 
higher compared to absolute control in field experiment. The total chlorophyll content at 30, 45 DAS were recorded $0.98,1.77$ which were 47 and $49 \%$ higher compared to absolute control in pot experiment. $\mathrm{K}$ application not only enhanced the availability of other nutrient but also increased the photosynthesis rate of mung bean Kumar et al., (2018). Adequate supply of potassium and phosphorus nutrient increase chlorophyll content in plants. These results are found to be similar with the results from Fletcher et al., (1982), Mfillage et al., (2014), Zhao et al., (2001). Significantly highest chlorophyll, carotenoids content as a result of foliar $\mathrm{K}$ nutrition could be attributed to the mode of action of macro elements in enhancing the photosynthetic activity Doss et al., (2013).Number of nodules plant ${ }^{-1}$ showed an increase with increasing level of potassium. Number of nodules plant ${ }^{-1}$ increased due to the soil application of $40 \mathrm{Kg} \mathrm{ha}^{-1}$ of SOP.

The treatment produced higher number of nodules plant $^{-1}$ at harvest was $49 \%$ higher compared to absolute control in field experiment. The above results obtained in the study are in conformity with the results of Khan and Prakash (2014), Kurdali et al.,(2002), Mir et al.,(2012) and Tahir et al.,(2013). Increase in the number of nodules plant $^{-1}$ might be due to addition of $\mathrm{K}$ applied in the initial stage which might have helped in the formation and growth of roots and formation of nodules has been reported by Sathiyamoorthi et al., (2008). Application of potassium (macronutrients) might have caused increased internal root growth, and enhanced the rhizobium activity in legumes. Similar findings were reported by Jack et al., (2000) and Suryalakshmi (2013). Leaf area index showed an increase with increasing level of potassium. Leaf area index significantly increased due to the soil application of $40 \mathrm{Kgha}^{-1}$ of SOP. The treatment produced higher leaf area index at
30, 45 DAS and harvest stage (which were 47, 29 and 27\% higher compared to absolute control in field experiments. Similar trend of results were observed in pot experiments. The leaf area index at 30, 45 DAS were 26, 24 and $21 \%$ higher compared to absolute control. The observed higher leaf area due to $\mathrm{K}^{+}$may be ascribed to its role in augmenting the cell size. The important role of potassium in the process of division and elongation of the cells and that reflects positively on leaf area Mengal and Arneke (1982), Tak et al., (2013). Application of potassium fertilizer gave the highest leaf area and with a significance difference. Leaf area index is owing to more number of branches and leaves. This might be due to optimum supply of nutrients which increased the plant growth, leaf number, leaf length and breadth. Similar results were also observed by Geetha and Velayutham (2009).

The present study concludes that application of potassium in the form of SOP $\left(\mathrm{K}_{2} \mathrm{SO}_{4}\right)$ at $40 \mathrm{~kg} \mathrm{ha}^{-1}$ increases the growth characters. This increase was due to the fact that role of potassium induces the process of division and elongation of cells and that reflects positive growth in plants.

\section{Acknowledgement}

I sincerely thank Dr. P.K. Karthikeyan Assistant Professor, Department of Soil Science and Agricultural Chemistry, AU for their timely help and guidance while conducting this research work.

\section{References}

Ali, A., Malik, M.A., Ahmad, R. and Atif, T.S. 1996. Response of mungbean to potassium fertilizer. Pakistan J. Agric. Sci., 33(1-4): 44-45.

Ali, R. and Muzquiz, M. 1998. ANFs in tropical legume seeds for human nutrition. In recent advances of research 
in anti-nutritional factors in legume seeds and rapeseed. Proceedings $3^{\text {rd }}$ International workshop on antinutritional factors in legume seeds and rapeseed. Wageningen, 8-10 July, pp. $107-122$.

Anonymous.2017. Heading of the table. http://www.indiastat.com.

Belitz, H.D. and Grosch, W. (eds.). 1996. Chemical composition. In: FoodChem., Springer Verlag., Berlin, Pp. 538.

Buriro, M., Hussain, F., Talpur, G.H., Gandahi, A.W. and Buriro, B. 2015. Growth and yield response of mungbean varieties to various potassium levels. Pak. J. Agric. Engg. Vet. Sci., 31(2): 203-210.

Darmadi-Blackberry, I., Wahlqvist, M.L., Kouris-Blazos, A., Steen, B., Lukito, W., Horie, Y. and Horie, K. 2004. Legumes: the most important dietary predictor of survival in older people of different ethnicities. Asia Pacific Journal of Clinical Nutrition, 13(2): pp.217-220.

Das, P.C. 1999. Plant nutrients. In: Manures and fertilizers. $2^{\text {nd }}$ ed. Kalyani publishers, New Delhi, India, pp: 5-10.

Doss, A., Anand, S.P. and Keerthiga, M. 2013. Effect of foliar application of diammonium phosphate (DAP), potash (K) and naphthalene acetic acid (NAA) on growth, yield and some biochemical constituents of (Vigna mungo (L.) Hepper). J. Agric. Res.,2(7): 206-208.

Fathima, A.A., Fardoas, R.H. and Rizkk, W.M. 2001. Effect of potassium fertilization on mungbean (Vigna radiata L. Wilczek). Egypt Appl. Sci.,16:156-167.

Fletcher, R., Kallidumbil, V. and Bhardwaj, S. 1982. Effect of fusicoccin on fresh weight and chlorophyll levels in cucumber cotyledons. Pl. Cell Physiol., 23: 717-719.

Geetha, P. and Velayutham. 2009.
Refinement of nutrient management techniques for growth, yield and nutrient uptake of rice fallow black gram. Madras Agric. J., 96(1-6): 163166.

Gomez, K.A. and A.A. Gomez. 1984. Statistical procedures for agricultural research (Ed.) A Willey Inter Science Publication, New York, USA.

Hasanuzzaman, M., Borhannuddin Bhuyan, M.H.M., Nahar, K., Hossain, Md. S., Al Mahmud, J., Hossen, Md. S., Masud, A.A.C., Moumita and Fujita, M. 2018. Potassium: A vital regulator of plant responses and tolerance to abiotic stresses. Agronomy, 8(31): 1-29.

Jack, A., Hartwigsen and Michael. 2000. Humic acid on seed treatment to promote the seedling root development in vegetable cowpea. Horti. Sci., 35(7): 1231-1233.

Karivaratharau, T.V. andRamakrishnan, V. 1985. Seed hardening studies in two varieties of ragi (Eleusine coracana). Indian Pl. Physiol., 28(3): 243-248.

Khairul Mazed, H.E.M., Yeasmin, M., Ferdous Moonmoon, J., Moniruzzaman, M. and Hassan Tareque, Md. 2016. The concentrations of $\mathrm{N}, \mathrm{P}, \mathrm{K}$ and $\mathrm{S}$ in mungbean stover and seed as influenced by potassium and sulphur application. Bull. Inst. Trop. Agri., Kyushu Univ., 39: 95-101.

Khan, K. and Prakash, V. 2014. Effect of rhizobial inoculation on growth, yield, nutrient and economics of summer urdbean (Vigna mungo L.) in relation to zinc and molybdenum. Int. J. Adv. Res. Chem. Chem. Engg., 1(1): 165-169.

Kumar, P., Kumar, P., Singh, T., Singh, A.K. and Yadav, R.I. 2014. Effect of different potassium levels on mungbean under custard apple based agri-horti system. Afr. J. Agric. Res., 9(8): 728734.

Kumar, S., Jakhar, D.S. and Singh, R. 2018. 
Growth and yield response of mung bean (Vigna radiata L.) in different levels of potassium. Acta Sci. Agri., 2(6): 23-25.

Kurdali, F., Farid Al-Aliand Shamma, M.A. 2002. Nodulation, dry matter production and $\mathrm{N}_{2}$ fixation by fababean and chickpea as affected by soil moisture potassium fertilizer. $J$. Pl. Nutr., 25(2): 355-368.

Mengel, K. and Kirkby, E.A. 1987. Principles of plant nutrition. $4^{\text {th }}$ Edition. Int. Potash Inst., Worblaufen-Bern, Switzerland.

Mfillage, A., KelvinMtei and Patrick Ndakidemi. 2014. Effect of rhizobium inoculation and supplementation with phosphorus and potassium on growth and total leaf chlorophyll $(\mathrm{Chl})$ content of bush bean (Phaseolus vulgaris L.). Agric. Sci., 5: 1413-1426.

Mir, A.H., Lal, S.B., Megna, R. and Samreen, M. 2012. Effect of phosphorus, sulphur and PSB on growth, yield and nutrient content in blackgram (Phaseolus mungo) and on soil properties. New Agriculturist, 23(2): 133-137.

Mustafa, R.., Al-Shaheen, Awangsoh and Ismaaiel, O.H. 2016. Effect of irrigation timing and potassium fertilizing on the some growth characteristics and production for mungbean (Vigna radiata L.). Int. J. Sci. Res. Publications, 6(3): 525-528.

Sahai, V.N. 2004. Mineral nutrients. In fundamentals of soil. $3^{\text {rd }}$ edition. Kalyani Publishers, New Delhi, India, pp. 151155.
Sathiyamoorthi, K., Amanullah, M.M., Somasundaram, E., Pazhaivelan, S. and Vaiyapuri, K. 2008. Root growth and yield of greengram (Vigna radiata (L.) Wilczek) as influenced by increased plant density and nutrient management .J. Appl. Sci. Res., 7:917-924.

Shahzad, N., Kanawl, S., Aziz, T. andMaqsood, M. 2014. Foliar application of potassium mitigates negative impact of water deficit stress and improves physiological growth of mungbean (Vigna radiata). p. 402.

Suryalakshmi, G.B. 2013. Studies on the enhancement of black gram productivity through humic acid and micronutrient cv. VBN 6 and ADT 36 M.Sc. (Ag.) Thesis, Annamalai University, Annamalai Nagar, Tamil Nadu.

Tahir, M., Hyder, A., Tahir, S., Naeem, M. and Rehman, A. 2013. Production potential of mungbean (Vigna radiata L.) in response to sulphur and boron under agro ecological condition of Pakistan. Int. J. Modern Agriculture,2(4): 166 - 172.

Tak, H.I., Babalola, O.O., Huyser, M.H. and Inam, A. 2013. Urban wastewater irrigation and its effect on growth, photosynthesis and yield of chickpea under different doses of potassium. Soil Sci. Pl. Nutri., 59(2): 156-167.

Zhao, D., Oosterhuis, D. and Bednarz, C. 2001. Influences of potassium deficiency, chlorophyll content and chloroplast ultrastructure of cotton plants. Photosynthetica, 39: 103-109.

\section{How to cite this article:}

Poovizhi Sindhu, G., K. Swetha Reddy, J. Gunasekar and Maragani Vamshi. 2019. Effect of Muriate of Potash (MOP) and Sulphate of Potash (SOP) on Growth Characters of Green gram (Vigna radiata (L.) Wilczek) cv. VBN 2 in Pot and Field Condition. Int.J.Curr.Microbiol.App.Sci. 8(02): 2577-2592. doi: https://doi.org/10.20546/ijcmas.2019.802.300 